Cinémas

Revue d'études cinématographiques

Journal of Film Studies

\title{
Scene and Surface in the Cinema : Implications for Realism
}

\section{Joseph D. Anderson}

Volume 12, numéro 2, hiver 2002

Cinéma et cognition

URI : https://id.erudit.org/iderudit/024880ar

DOI : https://doi.org/10.7202/024880ar

Aller au sommaire du numéro

Éditeur(s)

Cinémas

ISSN

1181-6945 (imprimé)

1705-6500 (numérique)

Découvrir la revue

Citer cet article

Anderson, J. D. (2002). Scene and Surface in the Cinema : Implications for Realism. Cinémas, 12(2), 61-73. https://doi.org/10.7202/024880ar

\section{Résumé de l'article}

Dans l'organisation visuelle d'un film, on peut distinguer deux ensembles distincts d'informations, l'un relatif à l'événement diégétique en trois dimensions (la scène) et l'autre, à l'écran bidimensionnel sur lequel le film est projeté (la surface). L'auteur, en collaboration avec ses collègues du Digital Arts and Imaging Lab, a essayé de déterminer quelle information était perçue comme faisant partie de la scène et quelle autre était considérée comme faisant partie de la surface. S'appuyant sur les travaux de James J. Gibson, il conclut en mettant en question l'application de la théorie du réalisme au cinéma. 


\title{
Scene and Surface in the Cinema: Implications for Realism
}

\author{
Joseph D. Anderson
}

\begin{abstract}
RÉSUMÉ
Dans l'organisation visuelle d'un film, on peut distinguer deux ensembles distincts d'informations, l'un relatif à l'événement diégétique en trois dimensions (la scène) et l'autre, à l'écran bidimensionnel sur lequel le film est projeté (la surface). L'auteur, en collaboration avec ses collègues du Digital Arts and Imaging Lab, a essayé de déterminer quelle information était perçue comme faisant partie de la scène et quelle autre était considérée comme faisant partie de la surface. S'appuyant sur les travaux de James J. Gibson, il conclut en mettant en question l'application de la théorie du réalisme au cinéma.
\end{abstract}

\section{ABSTRACT}

The visual array of a motion picture contains two separable sets of information, one for a three-dimensional diegetic event (scene) and another set of information which specifies the two-dimensional screen upon which the film is projected (surface). The author and his colleagues of the Digital Arts and Imaging Lab have attempred to sort out which information is seen as part of the scene and which as part of the surface. Based on the works of James J. Gibson, their conclusions question the application of the theory of realism to films.

That the motion picture embodies a perplexing duality has been apparent from the beginning. As early as 1916 the eminent psychologist Hugo Münsterberg ([1915] 1970, p. 19) puzzled 
[...] we know that we see a flat screen and that the object which we see has only two dimensions... Yet this is knowledge and not immediate impression. We have no right whatever to say that the scenes which we see on the screen appear to us as flat pictures.

And somewhat later, another distinguished psychologist, Rudolf Arnheim (1966, p. 26), ruminated that "[...] film, like the theater, provides a partial illusion [...]. It is always at one and the same time a flat picture post card and the scene of living action." This dual nature of the image remained an enigma that frustrated film scholars and resulted in their failure to achieve the desired clarity concerning either the nature of the image itself, or the relationship of the film viewer to the picture moving on the screen.

A quarter-century later the perceptual psychologist J. J. Gibson (1966, p. 235) confronted the problem again and observed that " $[\mathbf{t}]$ here is a curious paradox about a picture. It is neither a pure display on the one hand nor a pure deception on the other. The stimulus conveys information for both what it is physically and what it stands for." This insight concerning what the information contained in the image array specifies led to a functional definition of the situation that turns out to be very useful to film scholars. Gibson proposed that pictures, including motion pictures (or "progressive pictures" as he would have it) contain information for both a scene and a surface.

For a motion picture, "scene" would obviously refer to the three-dimensional world available to the characters in the fictional narrative, what film scholars have usually called the diegetic world. On the other hand, "surface" would include scratches on the film, digital artifacts like aliasing and cubeing, those stylistic devices that tend to ride up on the surface (such as titles and credits, intertitles and subtitles) as well as wipes, dissolves, irises, and other such transitional devices that call attention to the two-dimensional surface of the screen.

Similarly, two-dimensional graphic compositions are employed intentionally in many films. They are often ambiguous, sometimes being seen as abstract two-dimensional graphic compositions (surface) and at other times as part of the three- 
dimensional diegetic events (scene). For example, diagonal graphic patterns are employed by Sergueï Eisenstein in the early sequences of Battleship Potemkin (1925) where the sailors' quarters are seen as a maze of crowded hammocks hanging below deck, and then again as a dynamic two-dimensional composition of criss-crossing lines on the screen.

It is critical to realise that no visual array can be seen as both scene and surface simultaneously. As in the ambiguous figures of traditional perceptual psychology, the perceptions alternate. Just as the well-known rabbit-duck figure cannot be seen as a rabbit and as a duck at the same time, so too the motion picture (indeed any picture) cannot be seen as scene and as surface at the same time. I have argued elsewhere that when viewing a motion picture we are constantly in alternation between seeing the scene and seeing the surface, and that the perceptual alternation between scene and surface constitutes a framing of the motion picture viewing event, separating the experience of a motion picture from the experience of the real world, and serving as an intermittent reminder to the viewer that the scene in which he or she becomes involved is not the natural world but an image. ${ }^{1}$ Once the distincrion between scene and surface is recognised the enigma of realism begins to give up its secrets. No longer is the cliché that "no one is ever fooled into mistaking a motion picture for reality" a convincing refutation of motion picture realism.

Though there have been other directions, such as the fantasy films of Georges Méliès, the heavily stylized films of Robert Wiene and the German expressionists or the overtly constructed films of the Soviet Formalists, the main thrust of fiction film has been in the direction of realism. Even Sergueï Eisenstein, certainly not an avowed realist, chose to shoot the deck scenes of The Battleship Potemkin on a real battleship and to employ typecasting (rather than heavy make-up) to ensure the realism of both ship and characters. Potemkin endures as Eisenstein's masterpiece, and along with its striking examples of Soviet montage, is a high degree of realism. So it is not that filmmakers have always had an ideological commitment to realism per se, but that the films themselves have been more compelling to audiences when they have exploited the power of realism. 
There have been two major advocates of filmic realism, André Bazin and Siegfried Kracauer, who wrote respectively, What Is Cinema? (1971), and Theory of Film: The Redemption of Physical Reality (1960). Kracauer (p. 300) felt that somewhere along the way to our modern technologically dependent life we lost touch with the physical world. He went on to find in the motion picture a remedy:

Film renders visible what we did not, or perhaps even could not, see before its advent. It effectively assists us in discovering the material world with its psychophysical correspondences. We literally redeem this world from its dormant state, its state of virtual nonexistence, by endeavoring to experience it through the camera.

Bazin (1971, p. 14) advanced a similar view in discussing the differences between painting and film. He said:

Only a photographic lens can give us the kind of image of the object that is capable of satisfying the deep need man has to substitute for it something more than a mere approximation, a kind of decal or transfer. The photographic image is the object itself, the object freed from the conditions of time and space that govern it. [...] for photography does not create eternity, as art does, it embalms time, rescuing it simply from its proper corruption. Viewed in this perspective, the cinema is objectivity in time. The film is no longer content to preserve the object, enshrouded as it were in an instant, as the bodies of insects are preserved intact, out of the distant past, in amber.

If we make allowance for the fact that Kracauer and Bazin were both educated in a literary tradition rather than a scientific one, we find that their view of the motion picture's capacity for realism is actually rather compatible with Gibson's (1986, p. 293) when he says, with only a little less dramatic flare,

$[\ldots]$ the eye developed to register change and transformation. The retinal image is seldom an arrested image in life. Accordingly, we ought to treat the motion picture as the basic form of depiction and the painting or photograph as a special form of it. What a 
strange idea! It goes counter to all we have been told about optics. But it follows directly from ecological optics. Moviemakers are closer to life than picture makers.

Now the information available to us from a motion picture is greatly reduced from that available in the natural world, and as viewers we are constrained by the viewing situation. We cannot walk around and look at the event (at least not in ways other than those pre-selected for us by the filmmakers) or hear it from a different location. Nor can we taste, touch or smell the event being depicted. Yet there is still a great deal of information available to us, and an amazing aspect of motion picture viewing is that we seem to resonate to the information that is available, and never miss any information that might have been there but is not-unless some gap in information is called to our attention.

Most peculiarly much of the work on film perception over the last thirty years has gone towards explaining presumed gaps, the assumptions being first, that viewers are affected by the gaps, and second, that the mind must somehow fill in all gaps in information. The point to be made here is that the fact that motion pictures present only preselected information, and that the information is partial in several dimensions, does not seem to undermine a film's realism from the viewer's point of view.

The viewer's sense of realism is indeed so robust that my colleagues at the Digital Arts and Imaging Lab at Georgia State University and I set out to determine as systematically as possible what sorts of things might undermine that sense of reality. We assumed that it would be too easy to get viewers to note crude obvious problems that might detract from a film's realism, so we thought we would begin our study with the best digital effects that we could find, and we thought we should be able to find such effects in top-grossing Hollywood movies. So we selected clips from such films as Mission Impossible (De Palma, 1996), Twister (dD Bont, 1996), Titanic (Cameron, 1997), Apollo 13 (Howard, 1995), and Forrest Gump (Zemeckis, 1994). The clips were each about two to three minutes long and arranged in 
groups of five. We showed versions of these clips to groups of students, about twenty-five at a time. We told them that we had been asked to rate the clips on how real they looked, and that they should rate the scenes in an ongoing continuous way by twisting the dial on the responder unit that we had given each of them. We were able to see their responses in real time, individually and as a group, and to record this information for later analysis. We conducted group discussions after the trials to see what reasons they gave for their responses.

One of the manipulations was to introduce surface clutter into the image. The clutter was considerable, and of course in the video presentation these surface artifacts were in motion. The question of interest is whether viewers actually distinguish between surface and scene. Specifically, would viewers rate a clip with a high degree of surface clutter as less realistic than other clips without clutter in the same presentation or the same clip without clutter in another presentation? And the answer, perhaps startling to some, is that they did not. The implication we draw is that viewers do indeed distinguish between surface and scene, and that surface information is generally ignored when judging the credibility of the scene itself. In this situation and in most viewing situations the scene contains much more information than the surface; the scene contains information which specifies events and affordances and thereby demands the greater attention. ${ }^{2}$

Another question is what kind of information in the scene itself is most likely to undermine its realism. We found rather consistent drops in viewer judgments of realism at certain moments in the clips: 1) when Tom Cruise climbs on the helicopter or is hurled through the air in Mission Impossible; 2) when the bodies are tossed about on the deck of the Titanic; and 3) when the characters in Twister struggle through flying debris. The experimenters were, of course, watching the computer monitor and were able to observe the points where viewers suddenly shifted their evaluations of realism downward. In order to find out what the viewers themselves thought they were responding to, we asked them in the follow-up session. And we got answers such as: Tom Cruise and the helicopter didn't seem 
to "tug on each other" enough; the people on the Titanic didn't seem to "change their shapes appropriately" when they are tossed about the deck; and the man and woman in Twister didn't seem to be "hit by any of that stuff that was flying around."

The reports of the viewers were not inconsistent with the judgments of the experimenters. That is, the experimenters noted that precipitous declines in the graphs they were watching coincided with the effects of forces, wind, gravity, centrifugal, on bodies. The experimenters reported that viewers responded immediately and decisively to what they termed "small violations of the laws of physics." It would seem that the kinds of optical information to which our viewers responded most dramatically might be described as those which specify something amiss in ecologically relevant events-that is, those that indicate a problem with the ways in which objects or forces interact, a problem with ecological dynamics (Gibson, 1986, p. 182). These events can be described in terms of what Gibson has called "disturbances in the local structure of the optic array," most of them in the case of our study falling under the general category of deformation. Such disturbances, as Gibson (1986, p. 110) so eloquently puts it, "[...] are what we are visually most sensitive to, all of us, animals, babies, men, women, and moviegoers."

But now we have crossed over and are talking about the relationship of the viewer to the image. Bazin and Kracauer were on pretty solid ground in talking about the image's relationship to reality because they could rely on the process of photography, but they were more speculative when specifying the spectator's relationship to the image. They knew that to explain the spectator's relationship to the image they must in some way rely upon a theory of mind. Bazin drew upon phenomenology, and though Kracauer's theory was not explicitly phenomenological, he too addressed the experience of the individual spectator, claiming, like Bazin, that the cinematic image could present physical reality afresh, that it could, to use Bazin's phenomenological language, awaken in the spectator a sense of "being-inthe-world." But experientially based approaches like phenomenology as a theory of mind are often limited at best and at worst misleading. 
It is in this regard that Gibson's overarching ecological approach, which encompasses his insight regarding scene and surface, proves particularly useful. Ecological theory, like the theory of Bazin and Kracauer, takes into account the individual's experience, but Gibson is careful to ground his approach firmly in biology, reminding us at every turn that we as individuals always function as members of a larger species and within our particular ecological niche. We do not perceive all things, or take in all the available information. Or as evolutionary psychologist Henry Plotkin (1998, p. 193) has put it,

\begin{abstract}
[...] regular and reliable learning must indicate the presence of constraint because the search space is so large that unconstrained learning alone is extremely unlikely to succeed in finding the right things to learn in the short time available to the conscious experience of a newborn child. [...] The search space must be narrowed by something that aims the learning into a relatively tiny corner of all possible search space.
\end{abstract}

Traditional perceptual psychology assumes that perception begins with sensations and from those sensations the brain constructs a perception. Gibson came to question those assumptions and to realise that it was not a matter of construction that the human perceptual system was designed not to perceive sensations but to pick up information from the ambient array of light. The ecological approach to visual perception emphasises the information contained in the changing patterns of light available to the eye (or as Gibson called it, the ambient optic array). The changes in the optic array contain invariant properties that persist through changes in illumination and point of view, and these "invariants" specify objects or events in the world, which in turn inform action on the part of the viewer. In this ecological approach perception and action are "[...] tightly interlocked and mutually constraining" (Bruce and Green, 1990 , p. 224). The opportunity afforded for action is contained in the act of perceiving. It is a perceived opportunity for present or future action which Gibson calls an "affordance."

Let us consider the distinction between scene and surface in this context. In the perception of surface, whatever affordance 
there might be is clearly for the viewer, since the information is available only to members of the audience and never to the film's characters. And then there are affordances that are available only to the characters-food to eat, water to drink-and these are clearly part of the scene. But what about those scenes that are available to both character and viewer? One such scene is the filmic spectacle-a sunset, a sexually titillating shot. Such scenes may be for the viewer alone; there may be no character in a position to witness the scene. Or the spectacle may be available to both viewer and character(s). The spectacular sunset, for instance, affords an æsthetic experience for both the film viewer and the fictional characters who witness it. Yet other scenic events hold affordances only for the film viewer-for example, a shot in which the monster lunges toward the camera, looming on the screen. "These are sometimes called "startle shots," and it is the viewer who is startled.

Furthermore, the target of the affordances can shift within a shot or from one shot to the next. Consider, for example, a scene from Witness (Weir, 1985). The Amish widow Rachel Lapp (Kelly McGillis) leaves the kitchen, observed through the window from the backyard by John Book (Harrison Ford). The next several shots are of Rachel bathing. The scene appears to be an omniscient sequence of shots intended to be a spectacle designed for the pleasure of the film viewer alone until Book's presence in the doorway is revealed by his reflection in a mirror. The affordance that was previously for the viewer alone has become an affordance for both viewer and characters. But unlike the viewer, the characters are afforded not just spectacle but the opportunity for action. The characters' eyes meet (indicating a mutual affordance) and Rachel turns around, framed in the doorway, implicitly offering herself to Book, who hesitates, but soon makes the decision not to take advantage of the opportunity presented to him. This carries the scene to the level of narrative significance, providing a critical turning point in the subplot involving the mutual attraction of these two characters in the film.

The viewer's relationship with the diegetic world is further explained in this context. While we have sometimes toyed with 
the idea of the viewer entering the diegetic space, as though part of the fictional world, the concept has never seemed quite right. As viewers we knew we were not part of the fictional world, could not act upon that world or interact with it. The distinction made here between surface and scene, between affordances for the viewer and for the characters, makes it far more plausible that the viewer never enters the diegetic space, but that the spectacles on the screen sometimes invade the viewer's space, causing reactions that in retrospect might seem an odd response to an image, as we duck when an object is hurled at us from the screen, or lift our feet from the movie theatre's floor at the sight of a pit full of rattlesnakes, or recoil when the monster looms at us from the screen.

Let's pause at this point to note that the transition into talking about the individual perceiver is fraught with danger. There is great danger of losing one's footing on the slippery slopes of subjective experience, internal constructions and ultimately solipsism. Much film phenomenology ends up here. Gibson was aware of the need to address the individual perceiver's situation-his or her needs and (yes) desires, and he did so with the concept of affordances. But that does not mean that the ecological approach need therefore opens the door to relativism and solipsism. He was most careful to avoid these pitfalls, and warned of the "[...] danger of falling into the ridiculous pit of solipsism" (Gibson, 1982, p. 382), of "[...] concluding that we can know nothing but our perceptions. [...] Once having made this argument," he writes, "a theorist is trapped in a circle of subjectivism and is diverted into futile speculations about private worlds" (Gibson, 1959, p. 462-463).

It may be true that in terms of attention, there are moments during a movie when the viewer is so involved in the fictional events as to lose the sense of being in the theatre and attend only to the events of the diegetic world. The more compelling the diegetic events the longer the viewer will remain in that state before he or she regains the awareness of viewership. The pushpull in and out of the diegesis, and the alternation of awareness of scene and surface are dynamic, rhythmic patterns in film viewing. 
Because motion pictures have existed for a mere 100 yearsnot even a drop in the bucket of evolutionary time-we necessarily bring to the activity of film spectatorship capacities and strategies developed in another time for another purpose. Designed to extract veridical information from the ambient array of light in the natural world - that is, information that was accurate enough to act upon, our capacities are constrained by their evolutionary development; they are, as Henry Plotkin might put it, aimed into a tiny part of the possible search space. It is that search space that Gibson has identified as the ecological niche appropriate to human perception.

These are the capacities that we bring to the visual array regardless of the process by which the visual array was generated. And if these capacities were developed through evolution to enable us to extract accurate information, we will when presented with the visual array that is a motion picture extract information from it in the same way we do from the natural world. If that is the case, if the patterns of light reflected from a movie screen are processed by the visual system as though they were reflected directly from the surfaces of physical reality, then a theory of realism is clearly called for. If the film viewer interacts with patterns of light on the screen as he or she does with patterns of light in the world, then the relationship between the natural world and the image on the screen is not an insignificant matter; nor is an understanding of how the viewer interacts with the natural world (and by extension the film image) something that can be considered optional in a theory of film.

But a viewer perceives the depicted world, the "scene," as well as the physical display of flickering two-dimensional patterns of light on a beaded screen and the visual elements that are not available to the characters in the fictional world such as the titles, effects, wipes and dissolves. The latter might legitimately be included as part of "surface." But there is information other than surface information that should be considered in this context. There are elements such as inept make-up, poorly written dialogue, or bad acting, which, like surface elements, provide information for what the motion picture is rather than what it 
depicts. This is the central paradox of the motion picture, and it constrains and defines the experience of film viewing: The information available from the screen is both for a highly articulated fictional world and for the thing itself, the construction that constitutes a motion picture.

One may be able to dispense with the screen and minimize other information for surface as with virtual reality, and be left with a scene that is almost indistinguishable from reality. Yet this medium too contains information for both what it is and what it depicts, and this information also serves as a continual reminder to the viewer that he is viewing a constructed image. For any human construction the telltale marks of its crafting can be minimised but never completely expunged. This holds true for all forms of images, yet to the extent that any optic array before us fails to contain information that it has been scripted, casted, costumed, choreographed, acted, photographed, composited, projected, displayed, drawn, painted, carved or generated on a computer, the scene appears real.

University of Central Arkansas

\section{NOTES}

1. See The Reality of Illusion: An Ecological Approach to Cognitive Film Theory (Anderson, 1996, p. 43-49).

2. In his book, Sense of Order, E. H. Gombrich (1984) has provided compelling arguments that even when looking at non-representational decorative patterns we are drawn to the areas of highest information in a similar way.

\section{BIBLIOGRAPHICAL REFERENCES}

Anderson, 1996: Joseph D. Anderson, The Reality of Illusion: An Ecological Approach to Cognitive Film Theory, Carbondale, Southern Illinois University Press, 1996.

Arnheim, 1966: Rudolf Arnheim, Film as Art, Berkeley, University of California Press, 1966.

Bazin, 1971: André Bazin, What Is Cinema?, vol. I, Berkeley, University of California Press, 1971.

Bruce and Green, 1990: Vicki Bruce and Patrick R. Green, Visual Perception: Physiology, Psychology and Ecology, Hove, Lawrence Erlbaum Associates, 1990.

Gibson, 1959: James J. Gibson, "Perception as a Function of Stimulation," in

S. Koch. (ed.), Psychology: A Study of Science, vol. 1, New York, McGraw-Hill, 1959, p. $456-501$. 
Gibson, 1966: James J. Gibson, The Senses Considered as Perceptual Systems, Boston, Houghton Mifflin, 1966.

Gibson, 1982: James J. Gibson, "New Reasons for Realism," in Edward Reed and Rebecca Jones (ed.), Reasons for Realism: Selected Essays of Jarnes J. Gibson, Hillsdale, Lawrence Erlbaum Associates, 1982, p. 375-384.

Gibson, 1986: James J. Gibson, The Ecological Approach to Visual Perception, Hillsdale, Lawrence Erlbaum Associates, [1979] 1986.

Gombrich, 1984: Ernest H. Gombrich, Sense of Order: A Study in the Psychology of Decorative Art, London, Phaidon Press, [1979] 1984.

Kracauer, 1960: Siegfried Kracauer, Theory of Film: Redemption of Physical Reality, London, Oxford University Press, 1960.

Münsterberg, 19\%: Hugo Münsterberg, The Film: A Psychological Study, New York, Dover Publications Inc., [1916] 1970.

Plotkin, 1998: Henry Plotkin, Evolution in Mind: An Introduction to Evolutionary Psychology, Cambridge, Harvard University Press, 1998. 